\title{
Parasites in dairy cattle farms in southern Brazil
}

\section{Los parásitos en las granjas de ganado lechero en el sur de Brasil}

\author{
Roger Pascoeti, ${ }^{1}$ M.Sc, Natan Marcos Soldá, ${ }^{1}$ M.Sc, Tais Regina Sczesny, ${ }^{1}$ M.Sc, \\ Gustavo Machado, ${ }^{2}$ Ph.D, Caroline Zamperete Reginato, ${ }^{3}$ M.Sc, Giovana Camillo, ${ }^{3}$ Ph.D, \\ Fernanda Flores Vogel, ${ }^{3}$ Ph.D, Flávio José Simioni, ${ }^{1}$ Ph.D, Leandro Samia Lopes, ${ }^{1}$ Ph.D, \\ Juscivete Fatima Fávero, ${ }^{1}$ M.Sc, Aleksandro Schafer Da Silva, ${ }^{1 *}$ Ph.D.
}

\begin{abstract}
${ }^{1}$ Universidade do Estado de Santa Catarina (UDESC), Departamento de Zootecnia, Chapecó, SC, Brazil. 2Universidade Federal do Rio Grande do Sul (UFRGS), Laboratório de Epidemiologia Veterinária (EPILAB), Faculdade de Veterinária (FAVET), Porto Alegre, RS, Brazil. 'Universidade Federal de Santa Maria (UFSM), Departamento de Medicina Veterinária Preventiva, Santa Maria, RS, Brazil. Correspondence: aleksandro ss@yahoo.com.br
\end{abstract}

Received: April 2015; Accepted: September 2015.

\begin{abstract}
Objective. The aim of this study was to investigate the relation among type and size of the farms related to the management of production and especially the presence and control of parasites. Materials and methods. To accomplish the above, 65 farms were used: 56 of semi-extensive system (cows in pastures), classified as low density farms ( $n=15$, up to $15 /$ cows), medium density farms ( $n=20$; between $16-30 /$ cows) and large density farms ( $n=21$; over $31 /$ cows). It was also included nine farms freestall system ( $n=9$; confinement, over 70 cows) as part of the study population. Results. In the farms visited for the study can be noticed that the farms that had the higher level of technological improvement in managements practice were properties in high level (3) and freestall (4). In most of the farms there were observed the presence of ticks and flies, regardless of density of farms. Feces samples collected from 650 cows ( $n=10 /$ farm), and analyzed using McMaster showed that 191 cows were positive for parasites. The presence of antibodies in bulk milk tank occurred in $36\left(55.38 \% ; \mathrm{CI}_{95 \%}\right.$ 42-67) to Neospora caninum of the studied farms. Conclusions. We also conclude that $N$. caninum is present in cattle herds in Western Santa Catarina, and may be linked to reproductive problems in cows.
\end{abstract}

Key words: Cow, nematodes, neosporosis, production systems (Source: $C A B, M e S H$ ).

\section{RESUMEN}

Objetivo. El objetivo de este estudio fue investigar la relación entre el tipo y el tamaño de las fincas relacionadas con la gestión de la producción, y especialmente, la presencia y el control de los parásitos. Materiales y métodos. Para lograr lo anterior, se utilizaron 65 granjas: 56 de semi-extensivo sistema (vacas en los pastos), clasificado como granjas de baja densidad ( $n=15$, hasta $15 /$ vacas), las granjas de densidad media ( $n=20$; entre $16-30 / v a c a s)$ y granjas grandes densidad $(n=21$; más de 31 vacas). También se incluyeron nueve del sistema de granjas freestall ( $n=9$; confinamiento, más de 70 vacas) como parte de la población de estudio. Resultados. En las granjas visitadas se pudó notar que tenían el mayor nivel de mejora tecnológica en la práctica de gestiones eran propiedades en alto nivel (3) y estabulación libre (4). En la mayoría de las granjas no se observó la presencia de 
garrapatas y moscas, independientemente de la densidad de las explotaciones. Muestras de heces recogidas de 650 vacas ( $n=10 /$ granja), y analizados usando McMaster mostró que 191 vacas fueron positivas para parásitos. La presencia de anticuerpos en tanque de leche a granel se produjo en 36 (55.38\%; $\left.\mathrm{IC}_{95 \%} 42-67\right)$ por Neospora caninum de las fincas estudiadas. Conclusiones. Se concluye que $N$. caninum está presente en los rebaños de ganado en el oeste de Santa Catarina, y puede estar vinculado a problemas reproductivos en vacas.

Palabras clave: nemátodos, neosporosis, sistemas de producción, vaca. (Fuente: CAB, MeSH).

\section{INTRODUCTION}

The milk industry is an important component of agribusiness in Western Santa Catarina, Brazil. From this activity, the state reached an important contribution to gross domestic product (GDP) of the state of Santa Catarina, where dairy agribusiness still plays an extremely important role for the state, responsible for the survival of thousands of families in the countryside and in the generation of numerous direct and indirect jobs. Sanitary control herds are generally inefficient and can cause problems in production system, since they may be caused by various etiological agents, such as viruses, bacteria, fungi, and parasites $(1,2)$. Helminths are among the diseases that most affect livestock productivity in many regions of the world. In the 70s, it was estimated that each year about 10 million cattle and buffaloes died from consequences direct or indirect in presence of helminths (1). At present, it is believed that the number of animals with a fatal affection by parasites was reduced, due to strategic programs and new drugs; although significantly increased the diagnosis of treatmentresistant helminth (3). The damage caused by endoparasites can occur directly and indirectly reflected in weight gain, milk production, costs with antiparasitic, and mortality (1-3).

One of the main parasite that affects the Brazilian herd is the cattle tick Rhipicephalus (Boophilus) microplus, an ectoparasite that causes important economic losses in domestic cattle. Because of its ease way of reproduction, causes discomfort to the animals, as well as affect the development of the herd and the production of meat and milk. Furthermore, it can transmit diseases such as babesiosis and anaplasmosis, which can occur simultaneously and thus referred to as cattle tick fever (3). Besides the damage caused directly to the animal, the tick causes damage to the producer due to indirect spending with acaridae, labor and equipment necessities for application of such products (4). Another problem caused by tick relates to the environmental impact caused by the indiscriminate use of chemotherapeutic products. Over time, the difficulties in controlling the parasites increased significantly due to increasing resistance to chemotherapeutics in your control and treatment, often uncontrollable. Similarly, have

\section{INTRODUCCIÓN}

La industria de la leche es un componente importante de la agroindustria en el occidente de Santa Catarina, Brasil. A partir de esta actividad, el estado logró una importante contribución al producto interno bruto (PIB) del estado de Santa Catarina, donde las agroindustriales de lácteos todavía desempeñan un papel muy importante para el estado, y son responsables de la supervivencia de miles de familias en el campo y de la generación de numerosos empleos directos e indirectos. Las manadas de control sanitario son por lo general ineficientes y pueden causar problemas en el sistema de producción, ya que pueden ser causados por diversos agentes etiológicos, tales como virus, bacterias, hongos y parásitos $(1,2)$. Los helmintos se encuentran entre algunas de las enfermedades que más afectan la productividad ganadera en muchas regiones del mundo. En los años 70, se estima que cada año cerca de 10 millones de bovinos y búfalos murieron por consecuencias directa 0 indirectamente relacionadas con la presencia de helmintos (1). En la actualidad, se considera que se redujo el número de animales con una afección fatal por parásitos, debido a programas estratégicos y nuevos medicamentos; aunque se aumentó significativamente el diagnóstico de helmintos resistentes al tratamiento (3). El daño causado por los endoparásitos puede producirse directa e indirectamente en el aumento de peso, la producción de leche, los costos de antiparasitarios y la mortalidad (1-3).

Uno de los principales parásitos que afecta el rebaño brasileño es la garrapata Rhipicephalus (Boophilus) microplus, este es un ectoparásito que causa importantes pérdidas económicas en el ganado doméstico. Debido a su facilidad de reproducción, causa molestias a los animales y puede también afectar el desarrollo del rebaño y la producción de carne y leche. Además, puede transmitir enfermedades como la babesiosis y la anaplasmosis, que pueden ocurrir simultáneamente y que por tanto es conocida como fiebre de garrapata en bovinos (3). Además del daño causado directamente al animal, la garrapata causa daños al productor debido al gasto indirecto de acaridae, la mano de obra y los equipos necesarios para la aplicación de estos productos (4). Otro 
occurred with flies control, among these stands out the Musca domestica (often related to mastitis) and Haematobia irritans, a hematophagous insect that has caused serious damage to livestock $(3,5)$.

In this study we provide information about the Neospora caninum, the etiological agent responsible for neosporosis in cattle mainly. Recent studies have shown that several species of domestic animals can be infected, such as sheep, horses and goats $(3,6)$. The disease in cattle have been associated with clinical signs such as abortion, absorption, mummification or birth of weak calves (7), but usually the calves are born healthy, but infected, because the $N$. caninum can be transmitted congenitally. Horizontal transmission, i.e. ingestion of oocysts shed in the feces of the dog has been mentioned as a risk factor for disease (8).

Ticks, helminths and protozoa are responsible for diseases that cause economic problems for producers of milk will globally due to treatment costs and reduction in milk production (often unnoticed). In Santa Catarina Western, where you have a large milk cows stock, researches are limited. Therefore, the aim of this study was to investigate the relation between type and size of farms with production management and especially the presence of parasites, beyond the identification of risk factors related to infection by $N$. caninum.

\section{MATERIAL AND METHODS}

Local: Investigated properties. In this study 65 properties classified as specialized or semi specialized were surveyed (9) sampled from 20 municipalities in the western of Santa Catarina, Brazil (Figure 1). Of these, 56 semi-extensive system (cows in pastures), classified in this study as small (Class $1: \mathrm{n}=15$; up to 15 cows), medium (Class 2: $n=20$; between 16 and 30 cows) and large (Class 3: $n=21$; over 31 cows). Also as part of the study nine properties freestall system (Class 4: $n=9$; confinement, over 70 cows). The survey was conducted between November of 2013 and February of 2014, being applied a questionnaire for data collection, in order to verify the characteristics of the properties, as well as production and health management (Table 1).

Sample collection. During the visit at the farm was performed of collection of feces of 10 lactating cows, as well as a bulk milk tank. Feces were collected directly from the rectum, allocated into plastic containers, identified and stored in insulated cooler bags until analysis in the laboratory.

Parasitological analysis of feces. In the laboratory, the feces were processed by the problema causado por las garrapatas se relaciona con el impacto ambiental generado por el uso indiscriminado de productos quimioterápicos. Con el tiempo, las dificultades en el control de los parásitos se incrementaron debido al aumento de la resistencia a la quimioterapia en su control y tratamiento, que a menudo resulta incontrolable. Asimismo, se han producido con el control de moscas, entre estos destaca la mosca domestica (a menudo relacionada con mastitis) y Haematobia irritans, un insecto hematófago que ha causado graves daños a la ganadería $(3,5)$.

En este estudio ofrecemos información acerca del Neospora caninum, el agente etiológico responsable de la neosporosis en el ganado bovino principalmente. Estudios recientes han demostrado que varias especies de animales domésticos pueden ser infectadas, como ovejas, caballos y cabras $(3,6)$. La enfermedad en el ganado bovino se han asociado con signos clínicos como el aborto, absorción, momificación y nacimiento de terneros débiles (7), pero generalmente los becerros nacen sanos, pero infectados, porque el $N$. caninum puede ser transmitido congénitamente. La transmisión horizontal, es decir, la ingestión de ooquistes en las heces de perro, ha sido mencionada como un factor de riesgo para la enfermedad (8).

Las garrapatas, helmintos y protozoos son responsables de enfermedades que causan problemas económicos a los productores de leche a nivel mundial debido a los costos de tratamiento y la reducción en la producción de leche (a menudo inadvertida). En Santa Catarina occidental, donde hay un gran número de vacas lecheras, las investigaciones son limitadas. Por lo tanto, el objetivo de este estudio fue investigar la relación entre el tipo y el tamaño de las fincas con gestión de la producción y especialmente la presencia de parásitos, más allá de la identificación de los factores de riesgo relacionados con la infección por N. caninum.

\section{MATERIALES Y MÉTODOS}

Local: Predios investigados. En este estudio se analizaron 65 predios clasificados como especializada o semi-especializados (9), tomando muestras de 20 municipios en el oeste de Santa Catarina, Brasil (Figura 1). De estos, 56 pertenecían al sistema semi-extensivo (vacas en pastos), clasificados en este estudio como pequeños (Clase $1: n=15$; hasta 15 vacas), medios (Clase $2: n=20$; entre 16 y 30 vacas) y grandes (Clase $3: n=21$; por encima de en 31 vacas). Como parte del estudio también se incluyeron nueve predios del sistema freestall (Clase 4: n=9; confinamiento, más de 70 vacas). El estudio fue realizado entre noviembre de 2013 y febrero de 2014 utilizando un cuestionario 


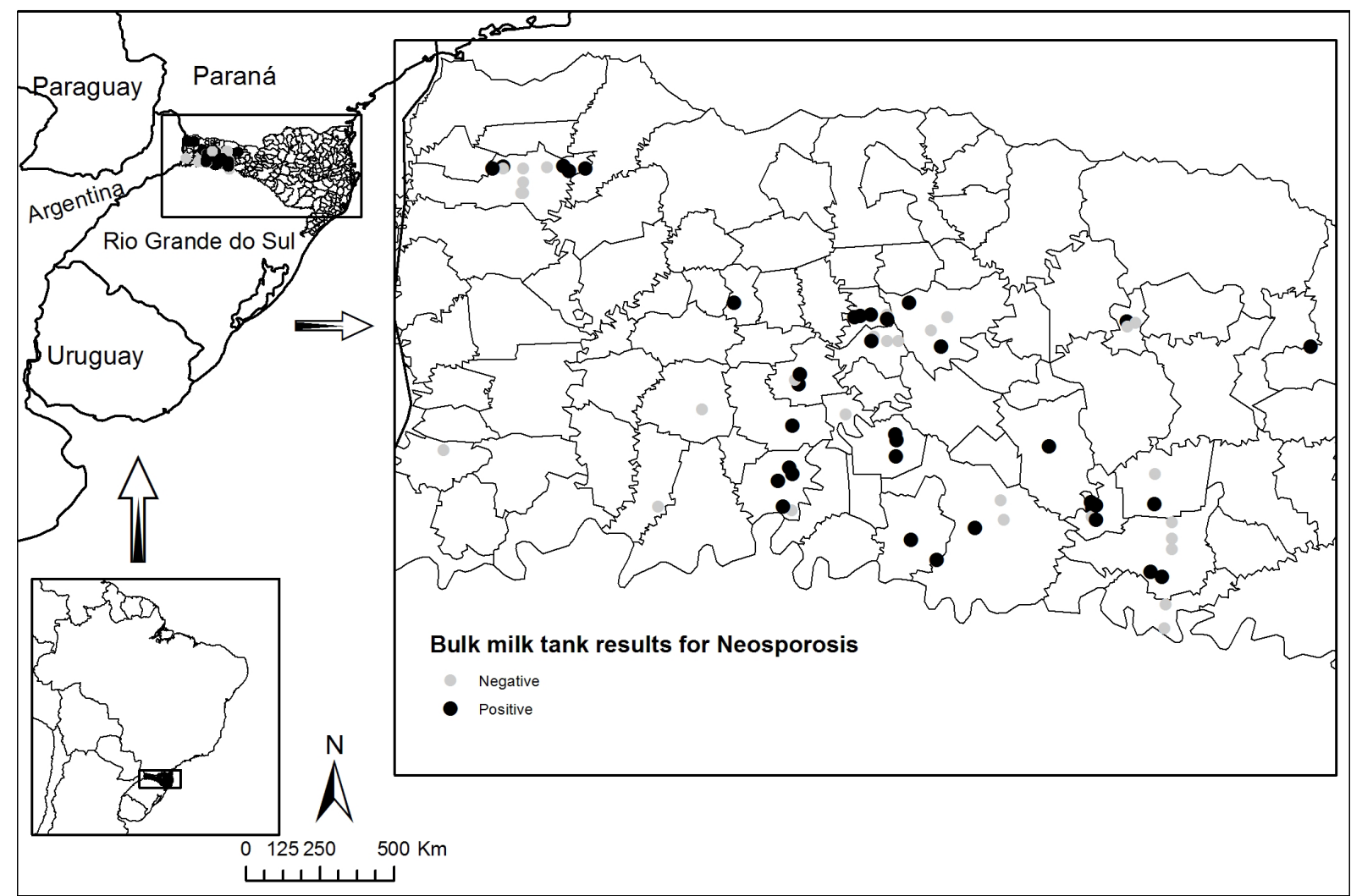

Figure 1. Map of epidemiological distribution of positive samples derived from milk from the farm tank, i.e. collective samples $(n=36)$ in a total of 65 samples in Santa Catarina state, Brazil.

McMaster technique, using supersaturated sugar solution to quantify the number of eggs per gram (EPG) of feces helminth (3). Of each farm was performed a pool of feces of the animals with positive EPG to carry out the culture of larval, kept in an incubator with constant temperature and humidity to identify helminths present on the farm.

\section{Serologic assay for Neospora caninum in bulk} milk tank. Milk collected from the tank of each farm was centrifuged at $7000 \mathrm{~g}$ for 10 minutes to obtain milk serum. So, the presence of antibodies to $N$. caninum in milk was verified by indirect immunofluorescence assay (IFA) using blades made with the protozoan tachyzoites (10). The samples considered positive were those in which full fluorescence from tachyzoites of $N$ caninum was observed, as described by Camillo et al. (11).To validate the tests, samples known as positive and negative were used as reaction control.

Data analysis. The relationship between the size of the properties for reproductive management and presence of parasites was performed only in a descriptive manner, seeking to identify management practices and sanitary control measurements of every classified type of farm. para la recolección de datos con el fin de verificar las características de los predios, así como la gestión de la producción y la salud (Tabla 1).

Recolección de muestras. La recolección de heces de 10 vacas así como un tanque de leche a granel se realizó durante la visita a las fincas. Las heces fueron recogidas directamente del recto, asignadas a envases plásticos, identificadas y almacenadas en bolsas frías aisladas hasta su análisis en el laboratorio.

Análisis parasitológico de heces. En el laboratorio, las heces fueron procesadas mediante la técnica de McMaster, usando una solución sobresaturada de azúcar para cuantificar el número de huevos por gramo (HPG) de helmintos en las heces (3). Se realizó un grupo de heces de animales con EPG positiva de cada granja para llevar a cabo el cultivo de las larvas, el cual fue mantenido en una incubadora a temperatura y humedad constante para identificar los helmintos presentes en la granja.

Análisis serológico para Neospora caninum en tanque de leche a granel. La leche recogida del tanque de cada finca fue centrifugada a $7000 \mathrm{~g}$ por 10 minutos para obtener el suero de la leche. 
Table 1. Information on management practices and occurrence of some parasitic diseases in dairy cattle farm in western Santa Catarina State, Brazil.

\begin{tabular}{|c|c|c|c|c|}
\hline Variable by farm & $\begin{array}{l}\text { Class } 1 \\
(n=15)\end{array}$ & $\begin{array}{l}\text { Class } 2 \\
(\mathrm{n}=\mathbf{2 0}) \\
\end{array}$ & $\begin{array}{l}\text { Class } 3 \\
(n=21) \\
\end{array}$ & $\begin{array}{c}\text { Class } 4 \\
(n=9)\end{array}$ \\
\hline Time dairy farming (years)* & $14.3 \pm 6.4$ & $19.9 \pm 8.6$ & $22.1 \pm 11.5$ & $6.1 \pm 5.4$ \\
\hline Number of total cow* & $13.4 \pm 2.7$ & $22.1 \pm 6.2$ & $49.7 \pm 22.5$ & $197.2 \pm 218.3$ \\
\hline Number of lactating cows* & $10.7 \pm 2.0$ & $17.7 \pm 5.82$ & $41.23 \pm 19.2$ & $123.8 \pm 78.0$ \\
\hline Milk production (liters/cow)* & $12.2 \pm 3.1$ & $17.4 \pm 4.8$ & $19.1 \pm 4.39$ & $27.2 \pm 3.4$ \\
\hline Compensation for milk quantity (\%) & 60.0 & 75.0 & 100 & 100 \\
\hline Compensation for milk quality (\%) & 46.6 & 95.0 & 100 & 100 \\
\hline Performs pre-dipping (\%) & 53.3 & 65.0 & 76.1 & 88.8 \\
\hline Performs pos-dipping (\%) & 80.0 & 85.0 & 90.4 & 100 \\
\hline Performs rapid test for mastitis\# (\%) & 60.0 & 80.0 & 47.6 & 77.7 \\
\hline Hand labor family (\%) & 100 & 95.0 & 76.1 & 44.4 \\
\hline Hand labor outsourced (\%) & 0.0 & 5.0 & 0.0 & 44.4 \\
\hline Hand labor family and outsourced (\%) & 0.0 & 0.0 & 23.9 & 11.1 \\
\hline Performs reproductive control (\%) & 80.0 & 100 & 100 & 100 \\
\hline Uses artificial insemination (\%) & 60.0 & 85.0 & 100 & 100 \\
\hline Using sexed semen (\%) & 6.6 & 15.0 & 19.0 & 33.3 \\
\hline Ration supply in the diet (\%) & 73.3 & 85.0 & 85.7 & 100 \\
\hline Supplying the silage in diet (\%) & 80.0 & 85.0 & 100 & 100 \\
\hline Existence of composter (\%) & 46.6 & 65.0 & 57.1 & 88.8 \\
\hline Presence of dogs (\%) & 100 & 90.0 & 90.4 & 66.6 \\
\hline Dogs have food access of cows: feeder and inputs (\%) & 73.3 & 45.0 & 57.1 & 66.6 \\
\hline Registration reproductive problems (\%) & 53.3 & 60.0 & 38.1 & 100 \\
\hline Tick control: acaricide (\%) & 66.6 & 90.0 & 80.9 & 55.5 \\
\hline Control of helminths: anthelmintics (\%) & 53.3 & 80.0 & 90.4 & 44.4 \\
\hline Performs rotation of antiparasitic (\%) & 40.0 & 90.0 & 66.6 & 33.3 \\
\hline Performs routine stool examinations (\%) & 0.0 & 10.0 & 9.5 & 33.3 \\
\hline Performs parasitic resistance tests (\%) & 0.0 & 15.0 & 9.5 & 0.0 \\
\hline Skin lesion in the mammary gland $(\%)^{\&}$ & 33.3 & 65.0 & 61.9 & 55.5 \\
\hline Presence of houseflies $(\%)^{+}$ & 33.3 & 70.0 & 71.4 & 100 \\
\hline Presence of the fly-horn $(\%)^{+}$ & 46.6 & 75.0 & 61.9 & 55.5 \\
\hline Babesiosis and anaplasmosis (\%) & 53.3 & 50.0 & 61.9 & 55.5 \\
\hline Number of cows with positive test feces for parasites per farm $(n=10)^{*}$ & $3.13 \pm 1.2$ & $3.1 \pm 1.7$ & $3.19 \pm 2.3$ & $1.6 \pm 1.5$ \\
\hline Mean EPG/farm & $42.3 \pm 91.0$ & $12.43 \pm 12.8$ & $31.2 \pm 46.3$ & $13.8 \pm 20.8$ \\
\hline Mean OOPG/farm & $11.3 \pm 15.3$ & $16.8 \pm 20.9$ & $25.4 \pm 69.2$ & $5.0 \pm 8.6$ \\
\hline Milk samples from seropositive for Neospora caninum per farm (\%) & 80.0 & 55.0 & 42.8 & 44.4 \\
\hline
\end{tabular}

* Mean \pm standard deviation; \#Testing black mug. ${ }^{*}$ Stephanofilariasis. ${ }^{+}$Observation made on the day of collection, the researchers.

Antibodies to Neospora caninum in milk. The data generated by the questioner applied records and by the test were recorded and analyzed in statistical software $R$, version 3.1 ( $R$ core team, 2012) and map was produced using Arc Map ${ }^{\circledR}$ version 3.2.1 (ESRI, Redlands, CA, USA). Cross tabulation and descriptive statistics were performed. Variables were first screened based on the response variable (positive or negative for Neosporosis), variables with large amounts of missing data ( $>10 \%$ ) and limited variability $(<20 \%)$ were not included in the multivariable model. The remaining variables were entered individually into a univariable logistic regression model and selected for inclusion in the multivariable model if $p<0.25$. Subsequently, all the screened variables were submitted to correlation analysis. The non-collinear variable was $<0.7$. Interactions
Así, la presencia de anticuerpos contra $N$. caninum en la leche fue verificada mediante un ensayo de inmunofluorescencia indirecta (IFA) utilizando láminas hechas con el protozoario taquizoitos (10). Las muestras consideradas como positivas fueron aquellas en las que se observó fluorescencia completa de taquizoitos de $N$ caninum, según lo descrito por Camilo et al. (11). Para validar las pruebas, las muestras conocidas como positivas y negativas fueron utilizadas como control de reacción.

Análisis de datos. La relación entre el tamaño de los predios para manejo reproductivo y la presencia de parásitos fue realizó únicamente de manera descriptiva, tratando de identificar las prácticas de manejo y medidas de control sanitario de cada tipo de finca clasificada. 
between all pairwise variables suitable for the final model were examined and, if significant $(p<0.05)$, were submitted to further analysis. Subsequently, the selected variables $(n=5)$, (Table 2 ) were included in the multivariable model. Multivariable models were built in a manual forward method; each remaining variable was added to the best previous model, selected by the Akaike Information Criterion (AIC) and Bayesian Information Criterion (BIC). A backward elimination step was finally used, resulting in a final model in which only variables with $p<0.05$ were retained. Confounding effects were investigated by checking changes in the point estimates of the variables that were kept in the model. Changes in parameter estimates $>25 \%$ were considered as a confounding factor, age was found to be a potential confounding factor and it was controlled during the regression. The goodness-of-fit of the final model was tested using Hosmer-Lemeshow (12).

Table 2. Univariate analysis of risk factors for Neospora caninum infection in bulk milk tank from 65 farms, in the state of Santa Catarina, Brazil.

\begin{tabular}{|c|c|c|c|}
\hline Variables & FD & $P$ - value & PR (IC 95\%) \\
\hline $\begin{array}{c}\text { Farm classification } \\
\text { Class } 1 \\
\text { Class } 2 \\
\text { Class } 3 \\
\text { Class } 4\end{array}$ & $\begin{array}{l}23 \\
31 \\
32 \\
13\end{array}$ & $\begin{array}{l}- \\
0.13 \\
0.03 \\
0.08\end{array}$ & $\begin{array}{l}- \\
0.30(0.08-1.11) \\
0.18(0.05-0.67) \\
0.20(0.04-0.92)\end{array}$ \\
\hline $\begin{array}{c}\text { Provides the silage diet } \\
\text { Yes }\end{array}$ & 90 & 0.18 & $4.51(0.71-28.62)$ \\
\hline No & 10 & - & - \\
\hline $\begin{array}{c}\text { Provides ration in the die } \\
\text { Yes }\end{array}$ & 84 & 0.11 & $3.83(0.98-15.17)$ \\
\hline No & 16 & - & - \\
\hline $\begin{array}{c}\text { Presence of dogs } \\
\text { Yes }\end{array}$ & 58 & 0.04 & $9.13(1.47-56.65)$ \\
\hline No & 7 & - & - \\
\hline $\begin{array}{l}\text { Dogs have contact input } \\
\text { supplied cows }\end{array}$ & & & \\
\hline $\begin{array}{l}\text { Yes } \\
\text { No }\end{array}$ & $\begin{array}{l}58 \\
41\end{array}$ & $\begin{array}{c}0.12 \\
-\end{array}$ & $\begin{array}{c}2.22(0.94-5.22) \\
-\end{array}$ \\
\hline $\begin{array}{c}\text { Reproductive problems } \\
\text { Yes }\end{array}$ & 57 & 0.80 & $1.13(0.49-2.59)$ \\
\hline No & 43 & - & - \\
\hline
\end{tabular}

$\mathrm{FD}=$ Frequency $(\%)$ or median (S.D.)

Parasitological feces. For the output of EPG variables were first screened based on the response variable count of Helminthes and Eimeria by descriptive statistics for contingency of the information and for further assumptions and what is presented as descriptive measurement is the mean and standard deviation. All variables were tested for normality of variance by Shapiro-Wilk test (13), skewness, kurtosis and homogeneity by Levene's test (14) previously to analysis by linear regression. Wald statistics was used to assess the
Anticuerpos contra Neospora caninum en la leche. Los datos generados por el cuestionario y por la prueba fueron registrados y analizados en el software estadístico R, versión 3.1 (equipo R, 2012) y se elaboró un mapa usando Arc Map ${ }^{\circledR}$ versión 3.2.1 (ESRI, Redlands, CA, EE.UU.). Se realizó estadística descriptiva y tabulación cruzada. En primer lugar las variables fueron analizadas con base en la variable de respuesta (positiva o negativa para Neosporosis), las variables con gran cantidad de datos faltantes ( $>10 \%$ ) y variabilidad limitada $(<20 \%)$ no fueron incluidas en el modelo multivariable. Las variables restantes fueron ingresadas individualmente en un modelo de regresión logística univariable y fueron seleccionadas para su inclusión en el modelo multivariable si $p<0.25$. Posteriormente, todas las variables seleccionadas fueron sometidas a análisis de correlación. La variable no colineal fue $<0.7$. Las interacciones entre todas las variables pares presentadas para el modelo final fueron examinadas $y$, en caso de ser significativas $(p<0.05)$, fueron sometidas a más análisis. Posteriormente, las variables seleccionadas $(n=5)$, (Tabla 2$)$ se incluyeron en el modelo multivariable. Los modelos multivariables fueron construidos mediante un método manual hacia adelante; cada variable restante fue agregada al mejor modelo anterior, seleccionado por el Criterio de Información de Akaike (AIC) y el Criterio de Información Bayesiano (BIC). Finalmente se utilizó un paso de eliminación regresivo, dando por resultado un modelo final en donde solo se conservaron las variables con $p<0.05$. Los efectos confusos fueron investigados mediante la comprobación de cambios en las estimaciones de las variables que se mantuvieron en el modelo. Los cambios en las estimaciones de parámetros $>25 \%$ fueron considerados como un factor de confusión, se encontró que la edad era un potencial factor de confusión y fue controlada durante la regresión. La bondad de ajuste del modelo final se evaluó mediante Hosmer-Lemeshow (12).

Heces parasitológicas. Para la obtención de las variables EPG, estas fueron analizadas en primer lugar con base en el recuento de respuesta variable de Helmintos y Eimeria mediante estadística descriptiva para la contingencia de la información y para supuestos adicionales y lo que se presenta como medida descriptiva corresponde a la media y desviación estándar. La normalidad de la varianza de todas las variables fue analizada mediante la prueba de Shapiro-Wilk (13), la asimetría, curtosis y homogeneidad mediante la prueba de Levene (14) de manera previa al análisis de regresión lineal. El estadístico de Wald fue utilizado para evaluar la significancia de la asociación (producción por clase de finca; control de Gelmintos y conteo de EPG) y la variabilidad del modelo fue expresada mediante $R^{2}$. 
significance of association (farm class production; Helminthes control and EPG count) and variability of the model was expressed by $\mathrm{R}^{2}$.

\section{RESULTS}

\section{Characterization of the farm as productive} management. The data relating to production management of the four classes divided by size and management system were presented in table 1 . Considering the average among the surveyed properties without considering size and production system, it was found that the time working in the dairy business was 17.7 years, as well as the frequency of the total number of cows and lactating cows were 53.3 and $38.2 \%$, respectively. The average milk production of the surveyed properties was 18.2 liters/day. From the properties it was found that the labor used in dairy cattle as familiar was $84.6 \%$, outsourced $(6.15 \%)$ and mixed (9.23\% - family and outsourced). In percentages, other important data relating to the farms studied were: receivable amount $(83.7 \%)$ and milk quality $(85.4 \%)$, performing pre-dipping $(70.8 \%)$, and post-dipping (88.8\%), rapid test for mastitis $(66.3 \%)$, reproductive control $(95 \%)$, use of artificial insemination (86.2\%), use of sexed semen $(18.4 \%)$, providing commercial feed $(86 \%)$ and silage (91.2\%).

\section{Relationship between farm and sanitary} control with emphasis on parasites. Considering the class 1, 2, 3 and 4 of the farms (size and system) for the sanitary handling and parasites were presented in table 1 . If we consider the 65 farms, without evaluating class, we found that $62.8 \%$ of the farms have shown reproductive problems. In percentages, was also identified farms investigated had composter for feces $(58.8 \%)$, presence of dogs $(86.7 \%)$, dogs with access to feeders and food $(60.5 \%)$, use of acaridae to control ticks $(73.2 \%)$, use of anthelmintic $(67 \%)$, rotation of anti-parasitic in the control of parasites $(57.4 \%)$, parasitological of feces with frequency $(13.2 \%)$, and resistance testing $(6.1 \%)$. This study also identified the occurrence of cranial injury to the udder of the cow, caused by the nematode Stefenofilaria sp. $(53.9 \%)$, and bovine babesiosis and anaplasmosis $(55.1 \%)$. On the farm, on the day of the visit, it was also found the presence of domestic fly (Musca domestica) and horn fly (Haematobia irritans) in 68.6 and $59.7 \%$, respectively.

Parasitological of faces. The results of EPG and OOPG (oocyst per gram) according to classification of the farms were presented in table 1 . Between farms investigated, only $9.23 \%$ were negative for parasites in feces, i.e., none of the cows showed helminthes eggs and coccidia oocysts in the

\section{RESULTADOS}

Caracterización de la granja de gestión productiva. Los datos relativos a la gestión de la producción de las cuatro clases divididas por tamaño y sistema de gestión se presentaron en la tabla 1. Teniendo en cuenta el promedio entre los predios encuestados sin tener en cuenta el tamaño y sistema de producción, se encontró que el tiempo de trabajo en el negocio de lácteos era de 17.7 años y la frecuencia del número total de vacas y vacas lactantes fue de 53.3 y $38.2 \%$, respectivamente. La producción de leche promedio de los predios encuestados fue de 18.2 litros/día. En los predios se encontró que la mano de obra utilizada en el ganado lechero era familiares (84.6\%), tercerizada $(6.15 \%)$ y mixta $(9.23 \%$ - familia y tercerizada). En porcentajes, otros datos de interés relativos a las fincas estudiadas fueron los siguientes: cantidad por recibir $(83.7 \%)$ y calidad de la leche $(85.4 \%)$, inmersión previa $(70.8 \%)$ e inmersión posterior $(88.8 \%)$, prueba rápida de mastitis $(66.3 \%)$, control de reproducción $(95 \%)$, uso de inseminación artificial (86.2\%), el uso de semen sexuado $(18.4 \%)$, alimentación comercial $(86 \%)$ y ensilado $(91.2 \%)$.

Relación entre la finca y el control sanitario con énfasis en parásitos. Teniendo en cuenta que las clases 1, 2, 3 y 4 de las fincas (tamaño y sistema) para manejo sanitario y parásitos fueron presentadas en la tabla 1 . Si tenemos en cuenta las 65 granjas, sin evaluar la clase, se encontró que el $62.8 \%$ de las granjas habían presentado problemas reproductivos. En términos porcentuales, también se identificó que las granjas investigadas contaban con un compostador para heces $(58.8 \%)$, presencia de perros $(86.7 \%)$, perros con acceso a comederos y alimento $(60.5 \%)$, uso de acaridae para controlar garrapatas $(73.2 \%)$, uso de antihelmíntico $(67 \%)$, rotación de antiparasitarios en el control de los parásitos $(57.4 \%)$, parasitológicos de heces con frecuencia $(13.2 \%$ ) y pruebas de resistencia $(6.1 \%)$. Este estudio también identificó la ocurrencia de lesiones craneales a la ubre de la vaca, causada por el nematodo Stefenofilaria sp. (53.9\%) y babesiosis y anaplasmosis bovina (55.1\%). En la granja, en el día de la visita, también se constató la presencia de moscas domésticas (Musca domestica) y moscas de los cuernos (Haematobia irritans) en un $68.6 \%$ y $59.7 \%$, respectivamente.

Parasitológico de heces. Los resultados de EPG y OOPG (ooquistes por gramo) según la clasificación de las granjas fueron presentados en la tabla 1. Entre las fincas investigadas, tan solo el $9.23 \%$ tuvieron un resultado negativo para parásitos en heces, es decir, ninguna de las vacas mostró huevos de helmintos y ooquistes de coccidios en las heces. Entre los animales que tuvieron unos resultados 
feces. Among animals positive for helminths, was observed variation between cows 50-3650 EPG, but in general, and average of $25.6 \mathrm{EPG} /$ animal. However, $80 \%$ of animals had positive EPG less than 300. Among the animals positive for coccidia, was detected variation between cows 50-3050 OOPG, but the overall average was 16.7 OOPG/animal.

No significant association was found between EPG counts and (farm class production; Helminthes control and OOPG count), as well as no significant association was found between OOPG counts and (farm class production; Helminthes control and EPG count). The oocysts in the faeces were identified as the genus Eimeria. The helminth eggs identified in the feces of cattle were of Trichostrongylus spp. (35.28\%), Haemonchus spp. (6.15\%), Teladorsagia spp. (1.53\%), Oesophagostomun spp. $(1.53 \%)$. In $33.84 \%$ of the farms was found mixed infection by two or three helminths.

Antibodies for $\boldsymbol{N}$. caninum in milk. The antibodies in milk farms were detected in 36 farms (55\%; $\mathrm{CI}_{95} \%$ 42-67) (Figure 1). When we consider the classification of the farm, was found higher occurrence in farms from class 1 (Table 2). In this study, a significant association was observed between following factors: classification of the farms (small, medium, large; freestall); providing concentrated to the cattle and access of dogs to the local storage of inputs supplied to animals with positive farms for neosporosis. Medium and large farms had higher risks of infection by $N$. caninum $\left(\mathrm{PR}=5.86-\mathrm{IC}_{95 \%}: 1.33-25.72\right)$ and $(\mathrm{PR}=8.32-$ $\left.\mathrm{IC}_{95 \%}: 1.95-35.40\right)$, respectively. It was also identified that the risk of infection by $N$. caninum is related to the supply of concentrate and access to the dogs feed stocks ( $\left.\mathrm{PR}=6.67-\mathrm{IC}_{95 \%}: 1.35-32.88\right)$ and $\left(P R=4.51-I_{95 \%}: 1.56-13.00\right)$, respectively (Table 3).

Table 3. Multivariate analysis of risk factors for Neospora caninum infection in bulk milk tank from 65 farms, in the state of Santa Catarina, Brazil.

\begin{tabular}{|c|c|c|c|}
\hline Variables & $\begin{array}{c}\text { Estimate } \\
(\boldsymbol{\beta})\end{array}$ & P - value & PR (CI: 95\%) \\
\hline Intercept & 0.14 & $<0.001$ & - \\
\hline \multicolumn{4}{|l|}{ Farm classification } \\
\hline Class 1 & - & - & - \\
\hline Class 2 & 1.70 & 0.04 & $5.86(1.23-25.72)$ \\
\hline Class 3 & 2.11 & 0.01 & $8.32(1.94-35.40)$ \\
\hline Class 4 & 1.50 & 0.10 & $4.90(0.95-25.09)$ \\
\hline \multicolumn{4}{|c|}{ Provides ration in the diet } \\
\hline $\begin{array}{l}\text { Yes } \\
\text { No }\end{array}$ & 1.89 & 0.05 & $6.47(1.35-32.88)$ \\
\hline & - & - & - \\
\hline \multicolumn{4}{|c|}{$\begin{array}{l}\text { Dogs have contact inputs } \\
\text { supplied cows }\end{array}$} \\
\hline Yes & 1.50 & 0.01 & $4.51(1.56-13.00)$ \\
\hline No & - & - & - \\
\hline
\end{tabular}

Hosmer test $=p=0.87$ positivos para helmintos, se observó una variación entre las vacas con 50-3650 EPG, pero en general y en un promedio de 25.6 EPG/animal. Sin embargo, el $80 \%$ de los animales tuvo un resultado positivo para EPG menor a 300. Entre los animales que resultaron positivos para coccidios, se detectó una variación entre las vacas con 50-3050 OOPG, pero el promedio general fue de 16.7 OOPG/animal.

No se encontró ninguna asociación significativa entre los conteos de EPG y (la producción por clase de finca; control de Helmintos y conteo de OOPG). Tampoco se encontró ninguna asociación significativa entre los conteos de OOPG y (la producción por clase de finca; control de Helmintos y conteo de EPG). Los ooquistes en las heces fueron identificados como del género Eimeria. Los huevos de helmintos identificados en las heces de los bovinos fueron de Trichostrongylus spp. (35.28\%), Haemonchus spp (6.15\%), Teladorsagia spp $(1.53 \%)$, Oesophagostomun spp (1.53\%). En el $33.84 \%$ de las fincas se encontraron infecciones mixtas por dos o tres helmintos.

Anticuerpos contra $\boldsymbol{N}$. caninum en la leche. Los anticuerpos en las granjas lecheras fueron detectados en 36 fincas ( $55 \%$; $_{95} \%$ 42-67) (Figura 1). Si tenemos en cuenta la clasificación de la granja, se encontró una mayor ocurrencia en las fincas de la clase 1 (Tabla 2). En este estudio, se observó una asociación significativa entre los siguientes factores: clasificación de las granjas (pequeña, mediana, grande, freestall); concentrado para el ganado y acceso de perros al almacenaje local de los insumos suministrados a los animales con las granjas con resultados positivos para neosporosis. Las fincas medianas y grandes tenían un mayor riesgo de infección por $N$. caninum $\left(\mathrm{PR}=5.86-\mathrm{IC}_{95} \%: 1.33-25.72\right)$ y $(\mathrm{PR}=8.32-$ $\left.\mathrm{IC}_{95} \%: 1.95-35.40\right)$, respectivamente. También se identificó que el riesgo de infección por $N$. caninum se encuentra relacionado con el suministro de concentrado y el acceso de perros a las existencias de alimento $\left(P R=6.67-I_{95} \%: 1.35-32.88\right)$ y $\left(P R=4.51-I_{95} \%: 1.56-13.00\right)$, respectivamente (Tabla 3).

\section{DISCUSIÓN}

La clasificación de la granja por el número de vacas lecheras para verificar la diferencia numérica con respecto a la gestión, producción y control sanitario, es algo esperado debido a los diferentes grados de mejora tecnológica. Por ejemplo, los niveles de proteína y grasa en la leche son más pequeños en fincas que tienen un mayor nivel de tecnología de producción, pero a cambio estas granjas tienen un menor número de recuento de células somáticas (SCC) y recuento bacteriano total (TBC) (9). La explicación de este comportamiento puede 


\section{DISCUSSION}

The classification of the farm by number of dairy cows provided to verify numerical difference regarding managements, production and sanitary control, something expected due to the different degrees of technological improvement. For example, levels of protein and fat in milk are smaller farms that have a higher level of production technology, but in return these farms have lower number of somatic cell count (SCC) and total bacterial count (TBC)(9). The explanation for this behavior may be due to improved nutrition of animals and use of specialized breeds with the increase in production levels. Another point related to the production this hygiene practices at farm, observed in this study in a good sizeable percentage (pre-dipping, post-dipping and mastitis test); however, these practices were lower on farms of small and medium size (class 1 and 2) the extensive system. According of Simioni et al (9) and Martins et al (15), in specialized farms, the dairy cattle shows greater economic importance, encouraging the farmers to adopt appropriate hygiene practices during milking, and reproduction of the herd; similar to that observed in this study.

Ectoparasites are also factors that can cause loss in milk production, and the farms visited the main ectoparasites were identified to flies (Musca domestica and Haematobia irritans) and ticks (Rhipicephalus microplus). These flies can cause chronic dermatitis in cattle (horn fly), as well as being vectors of mastitiscausing bacteria (16), and nematode that causes stefanofilariosis, characterized by skin lesions, cranial to the mammary gland of the cow, caused by the genus Stephanofilaria (17), observed in this study, in a high percentage (56\%) farms investigated. Approximately $62 \%$ of farms are facing serious problems with outbreaks of flies during the year, independent of the class 1 to 4 in this study. The presence of composters can help control flies (3), but only $60 \%$ used on farms in the west of Santa Catarina State.

According to the literature, ticks are the most important ectoparasites for dairy farming, and approximately $75 \%$ of the cattle population is affected by this parasite. Tropical and subtropical regions are favorable for the development of ticks (4), target region this study. In addition to direct damage to the animal, the tick transmits Babesia spp. and Anaplasma spp. (3), responsible for causing one of the most common diseases (bovine parasitic sadness) in dairy cows in the Brazilian deberse a la mejora en la nutrición de los animales y el uso de razas especializadas con el aumento correspondiente en los niveles de producción. Otro punto relacionado con la producción es prácticas higiénicas en la finca, observadas en este estudio en un porcentaje considerable (prueba de inmersión previa, inmersión posterior y mastitis); sin embargo, estas prácticas fueron inferiores en granjas de pequeño y mediano tamaño (clase 1 y 2) del sistema extensivo. Según Simioni et al (9) y Martins et al (15), en granjas especializadas, el ganado lechero muestra una mayor importancia económica, alentando a los agricultores a adoptar prácticas de higiene adecuadas durante el ordeño y la reproducción de la manada; similar a lo observado en este estudio.

Los ectoparásitos son factores que también pueden causar pérdidas en la producción de leche, y en las granjas visitaron los principales ectoparásitos identificados fueron moscas (Musca doméstica y Haematobia irritans) y garrapatas (Rhipicephalus microplus). Estas moscas pueden causar dermatitis crónica en los bovinos (mosca de los cuernos), así como servir de vectores para bacterias causantes de mastitis (16) y nematodos que causan la stefanofilariosis, las cuales se caracterizan por lesiones cutáneas y craneales a la glándula mamaria de la vaca, producidas por el género Stephanofilaria (17), observado en este estudio, en un alto porcentaje (56\%) de fincas investigadas. Aproximadamente el $62 \%$ de las granjas se enfrentan a graves problemas de brotes de moscas durante el año, independiente de la clase 1 a 4 en este estudio. La presencia de compostadores puede ayudar en el control de las moscas (3), pero son utilizados por tan solo el $60 \%$ de las granjas en el oeste del estado de Santa Catarina.

Según la literatura, las garrapatas son los ectoparásitos más importantes para la ganadería lechera, y aproximadamente el $75 \%$ de la población de ganado es afectada por este parásito. Las regiones tropicales y subtropicales resultan favorables para el desarrollo de las garrapatas (4), las cuales corresponden a la región objetivo de este estudio. Además del daño directo para el animal, las garrapatas transmiten Babesia spp y Anaplasma spp (3), los cuales son responsables de causar una de las enfermedades más comunes (tristeza parasitaria bovina) en vacas lecheras en los estados brasileños. En este estudio esto no fue diferente, se encontró que el $58 \%$ de las fincas tienen casos anuales de babesiosis y anaplasmosis, independientemente de la clasificación dada en el presente estudio. La enfermedad es una de las mayores pérdidas económicas debido a problemas sanitarios en el ganado debido a los costos del tratamiento, las altas tasas de mortalidad y morbilidad, así como reducción en la producción de 
states. This study was no different, as the interview was found that $58 \%$ of farms have annual cases of babesiosis and anaplasmosis, regardless the classification given in this study. The disease is a sanitary problems greatest economic loss in cattle due to treatment costs, high rates of mortality and morbidity, as well as reduction in the production of meat and/or milk $(3,18)$. Most farms investigated make use of antiparasitic to control ticks, and only $16 \%$ of farms do not tick control, because according to the producers the degree of infestation is low. This can be explained because these farms are rotational grazing system or animals are in confinement (freestall), which reduces the chance of development of the parasite, and contact with animals.

The EPG generally considered low, as observed by Pasetti et al (2), however, the number of infected animals was superior in study current. Helminthes were identified Strongylida order, being the Trichostrongylus spp the most frequent $(35.28 \%)$, similar of observed in Minas Gerais state by Araujo (19) in dairy cows. In this study, it was found that about $72 \%$ of farmers perform routinely the anthelmintic treatment, usually in the dry cow period, having a preventive effect. Despite the presence of Eimeria spp. oocysts in the feces of cattle, no treatment for coccidiosis is done, but according to the literature infection cause destruction of intestinal cells, and consequently interferes with the absorption of nutrients (3)

Our model was able to identify the presence of dogs as a risk factor for $N$. caninum, this finding is well reported on many studies and it's a very important epidemiological factor since dogs become $N$. caninum definitive hosts (20), but what we found provide more detail to this issue. It was found that the possibility of a dog having contact with cattle fed, what includes stocked food represent a challenging risk factor for $N$. caninum infectious. Our finds are in accordance with others that have shown that farm dogs may defect on feeding alleys and on stored grass or corn silage what may cause evidence of postnatal bovine infection than by those of herds with no such evidence $(21,22)$. Based on these results, it may be justified to assume that contaminations of the feeding area are more closely related to $N$. caninum infection (23). Complementary to the factor above it was also find that farms how provide concentrate to the cattle were more likely to be positive for $N$. caninum, this knowledge is in accordance to Topazio et al (6) that have shown that goats farms that provide rich diet what included concentrate have more chances carne y/o leche $(3,18)$. La mayoría de las granjas investigadas hacen uso de antiparasitarios para el control de las garrapatas, y tan solo el $16 \%$ de las granjas no tienen ningún control para las garrapatas, porque según los productores, el grado de infestación es bajo. Esto puede explicarse por qué estas granjas tienen un sistema de pastoreo rotacional o por que los animales se encuentran en confinamiento (freestall), lo que reduce las posibilidades de desarrollo del parásito y el contacto con los animales.

La EPG es considerada como baja en general, según lo observado por Pasetti et al (2), sin embargo, el número de animales infectados fue superior en el estudio actual. Se identificaron Helmintos del orden Strongylida, siendo el Trichostrongylus spp. el más frecuente (35.28\%), de forma similar a lo observado en el estado de Minas Gerais por Araujo (19) en vacas lecheras. En este estudio, se encontró que aproximadamente el $72 \%$ de los agricultores realizan rutinariamente un tratamiento antihelmíntico, generalmente en el período seco, ya que tiene un efecto preventivo. A pesar de la presencia de ooquistes de Eimeria spp. en heces del ganado, no se realiza ningún tratamiento para la coccidiosis, pero según la literatura la infección provoca la destrucción de las células intestinales y por lo tanto interfiere con la absorción de nutrientes (3).

Nuestro modelo fue capaz de identificar la presencia de perros como un factor de riesgo de $N$. caninum, este hallazgo ha sido ampliamente reportado en muchos estudios y es un factor epidemiológico muy importante puesto que los perros se convierten en anfitriones definitivos de $N$. caninum (20), pero lo que encontramos brinda más detalles en esta cuestión. Se encontró la posibilidad de que un perro tenga contacto con el alimento para ganado, lo que significa que los alimentos almacenados representan un difícil factor de riesgo para $N$. caninum infeccioso. Nuestros hallazgos son consistentes con otros que han demostrado que los perros de granja pueden defecar en los corredores de alimentación y en hierba almacenada o ensilado de maíz, lo que puede causar evidencia de infección puerperal bovina que los rebaños con ninguna evidencia de este tipo $(21,22)$. Con base en estos resultados, puede estar justificado suponer que la contaminación de la zona de alimentación se encuentra más estrechamente vinculada con la infección por $N$. caninum (23). De manera complementaria al factor anterior, se encontró también que las granjas que ofrecen concentrado a los ganados eran más propensas a tener resultados positivos para $N$. caninum, este conocimiento es consistente con Topazio et al (6) donde se ha demostrado que las cabras de granja que con una rica dieta qué incluye concentrado tienen más 
of the infections, and a possible explanation for these may due to inadequate food storage what may make possible a direct contact between fed and infected dogs. Finally, larger farms were identify on the study as class 2 and 3 were associated to risk of $N$. caninum infection, in a study from Italy, the risk of individual cattle becoming seropositive increased with the size of the herd. When the analysis was restricted to data from northern Italy, the number of dogs per farm interacted significantly with herd size; i.e., the risk of being seropositive increased in larger herds with an increasing number of dogs per farm (24) in addition a study conducted in Germany, larger herds had an increased risk of being bulk milk positive (25). An explanation for herd size as a risk factor could be that hygienic measures to prevent dogs from feeding on placentas or other infectious material are more difficult to follow with large herds than with small herds (25).

In summary, we can conclude that there are technical differences between the farms, which is reflected in handling and production, i.e. the largest farms (Class 3 and 4 ) can produce a greater volume of milk, as is best compensated, reflecting to increased investment in the farm (technification). The contamination by gastrointestinal parasites had no difference between production systems. Also concluded that over $50 \%$ of farms in western Santa Catarina has infected cows by $N$. caninum, which may be related to reproductive problems reported by producers. The detection of antibodies to $N$. caninum in collective samples of milk proved to be a great diagnostic tool to herd, reducing costs with individual tests in a research first.

Ethics committee. Experimental protocol was approved by the Animal Welfare Committee of Universidade do Estado de Santa Catarina (UDESC) under number 1.23.14. posibilidades de sufrir infecciones, y una explicación posible de esto puede deberse al almacenamiento inadecuado de alimentos que puede posibilitar un contacto directo entre perros alimentados e infectados. Por último, en las granjas grandes que se identifican en el estudio como clases 2 y 3 se asociaron al riesgo de infección por $N$. caninum, en un estudio realizado en Italia, el riesgo de que e ganado individual sea seropositivos aumenta con el tamaño de la manada. Cuando el análisis se restringió a los datos del norte de Italia, el número de perros por finca interactúa significativamente con el tamaño del hato; es decir, el riesgo de ser seropositivos en manadas más grandes aumenta con un mayor número de perros por finca (24), además de un estudio realizado en Alemania, manadas más grandes mostraban un riesgo mayor de resultar positivos a la leche a granel (25). Una explicación para el tamaño de la manada como un factor de riesgo podría ser que las medidas higiénicas para evitar que los perros se alimentan de placentas u otros materiales infecciosos son más difíciles de seguir con las manadas grandes que con rebaños pequeños (25).

En Resumen, podemos concluir que existen diferencias técnicas entre las granjas, lo que se refleja en el manejo y producción, es decir que las fincas más grandes (Clase 3 y 4 ) pueden producir un mayor volumen de leche, ya que está mejor compensado, lo que refleja una mayor inversión en la granja (tecnificación). La contaminación por parásitos gastrointestinales no muestra ninguna diferencia entre los sistemas de producción. También se llegó a la conclusión que más del $50 \%$ de las granjas en el oeste de Santa Catarina tienen vacas infectadas por $N$. caninum, lo que puede estar relacionado con los problemas reproductivos reportados por los productores. La detección de anticuerpos contra $N$. caninum en muestras colectivas de leche ha demostrado ser una gran herramienta de diagnóstico para la manada, reduciendo los costos con pruebas individuales en una investigación.

Comité de ética. El protocolo experimental fue aprobado por el Comité de Bienestar Animal de la Universidade do Estado de Santa Catarina (UDESC) bajo el número 1.23.14.

\section{REFERENCES}

1. Herlich $\mathrm{H}$. The importance of helminth infections in ruminants. World Anim Rev 1978; 26(1):2226.
2. Pasetti M, Da Silva AS, Simioni $F$, Lima $\mathrm{HL}_{\text {, }}$ Battiston J, Stefani LM. Parasitological study on cows during lactation in western Santa Catarina, Brazil. Acta Scie Vet 2012; 40:1058. 
3. Monteiro SG. Parasitologia Veterinária. São Paulo, Roca; 2010.

4. Pazinato R, Klauck V, Grosskopf RK, Dalla Rosa L, Volpato A, Baretta D, Stefani LM, Da Silva AS. Antiparasitic Resistance of Different Populations of ticks (Rhipicephalus microplus) in the Western of Santa Catarina State, Brazil. Acta Scie Vet 2014; 42:1206.

5. Klauck V, Pazinato R, Stefani LM, Santos RC, Vaucher RAM, Baldissera D, et al. Insecticidal and repellent effects of tea tree andiroba oils on flies associated with livestock. Med Vet Entomol 2014; 28(1):33-39.

6. Topazio J, Da Silva AS, Lopes LS, Ribeiro A, Weber A, Noll JCG, et al. Seroprevalence and risk factors for Neospora caninum in goats in Santa Catarina state, Brazil. Rev Bras Parasitol Vet 2014; 23(1):1-7.

7. Parra BC, Parra BS, Neves FN. Neosporose uma doença que acomete abortos em bovinos. Rev Cient El Med Vet 2008; 6(1):1-5.

8. Santos RRD, Rocha CMBM, Guimarães AM Quantification of vertical transmission of Neospora caninum in dairy cows in Minas Gerais, Brazil. Rev Bras Parasitol Vet 2012; 21(3):294297.

9. Simioni FS, Baretta CRDM, Stefani LM, Lopes LS, Tizziani T. Qualidade do leite proveniente de propriedades com diferentes níveis de especialização. Semina: Ciênc Agr 2013; 34(4):1901-1912.

10. Paré J, Hietala SK, Thurmond MC. Interpretation of an indirect fluorescent antibody test for diagnosis of Neospora sp. infection in cattle. J Vet Diag Invest 1995; 7(3):273-275.

11. Camillo G, Cezar AS, Antonello AM, Sangioni LA, Flores EF, Pereira GR, Gonçalves PBD Vogel FSF. Detecção de anticorpos anti-Neospora caninum em amostras individuais e coletivas de leite de bovinos pela reação de imunofluorescência indireta. Pesq Vet Bras 2011; 31(3): 482-486.

12. Dohoo I, Martin W, Stryhn H. Veterinary Epidemiologic Research. Inc; Charlottetown: 2009.

13. Shapiro SS, Wilk MB. An analysis of variance test for normality: complete samples. Biometrika 1965; 52(4):591-611.

14. Box GEP. Non-normality and tests on variances. Biometrika 1953; 40(2):318-335.
15. Martins PR, Fischer $V$, Ribeiro MER, Gomes JF, Stumpf Júnior W, Zenala MB. Produção e qualidade do leite em sistemas de produção da região leiteira de Pelotas, RS, Brasil. Ciênc Rural 2007; 37(2):212-217.

16. Nickerson SC, Owens W, Boddie RL. Mastitis in dairy heifers: initial studies on prevalence and control. J Dairy Sci 1995; 78(6):1607-1618.

17. Miyakawav I, Dos Reis ACF, Lisbôa JAN Estefanofilariose em bovinos. Semina: Ciênc Agr 2010; 31(3):479-486.

18. Doyle RL, Da Silva AS, Oliveira CB, França RT, Martins JR, Lopes STA, Melazzo C. Lipid peroxidation and decrease on the activities of antioxidant enzymes in experimental infection by Babesia bovis in cattle. Comp Clin Pathol 2015; doi: 10.1007/s00580-015-2077-0.

19. Araujor N, Limaw S. Infecções helmínticas em um rebanho leiteiro na região Campo das Vertentes de Minas Gerais. Arq Bras Med Vet Zoot 2005; 57:186-193.

20. Almeria S. Neospora caninum and Wildlife. ISRN Parasitol 2013; 2013: 947347.

21. Martínez A, Álvarez-García I, Arnaiz-Seco E, Ortega-Mora LM. Use of avidity enzyme-linked immunosorbent assay and avidity Western blot to discriminate between acute and chronic Neospora caninum infection in cattle. J Vet Diag Invest 2005; 17:442-450.

22. Aguiar DM, Lacerda DP, Orlandelli RC, Medina AO, Azevedo SS Prevalence of anti-Neospora caninum antibodies in cattle and dogs from Western Amazon, Brazil, in association with some possible risk factors. Vet Parasitol 2006; 142(1):71-77.

23. Dubey JP, Schares G, Ortegamora LM. Epidemiology and control of Neosporosis and Neospora caninum. Clin Microbiol Rev 2007; 20(2):323-369.

24. Otranto DA, Lazari A, Testini G, Traversa D, Di Regalbono AF, Badan M, Capelli G. Seroprevalence and associated risk factors of neosporosis in beef and dairy cattle in Italy. Vet Parasitol 2013; 118(1):7-18.

25. Schares G, Bärwald $A$, Staubach C, Ziller M, Klöss D, Schroder R, Labohm R, Dräger K, Fasen W, Hess RG, Conraths FJ. Potential risk factors for bovine Neospora caninum infection in Germany are not under the control of the farmers. Parasitol 2005; 129(2):301-309. 